October 28,2002

\title{
Pax-Americana-led Macro-Clustering and Flying-Geese-Style Catch-Up in East Asia: Mechanisms of Regionalized Endogenous Growth
}

\author{
Terutomo Ozawa \\ Department of Economics \\ Colorado State University \\ Fort Collins, CO. 80523-1771 \\ Phone: (970) 491-6075 \\ Fax: (970) 491-2925 \\ E-mail: TEOZAWA@LAMAR.COLOSTATE.EDU
}

This paper is a revised version of the paper presented at the $24^{\text {th }}$ ACAES International Conference on Asian Economics held at Beida School of Economics, Peking University, Beijing, China, May 27-29,2002. An earlier version is forthcoming in the Journal of Asian Economies.

\section{ABSTRACT}

Rapid growth in East Asia (despite the 1997-98 crises) has been unique as it is clustered so intensively only in that particular region. The flying-geese model of industrial upgrading is applied to the emergence of Pax-Americana-led growth clustering. The high propensity of the U.S. to transplant manufacturing overseas, Japan's roles of structural intermediator and capacity augmenter, and catching-up economies' public policies are the key co-determinants of regionalized endogenous growth in East Asia.

JEL classification: O3; O5; O14; F2; F21

Keywords: Pax-Americana; Flying-geese model, Tertialization; Capacity augmenter. Production fragmentation; Regional endogenous growth 


\title{
Pax-Americana-led Macro-Clustering and Flying-Geese-Style Catch-Up in East Asia: Mechanisms of Regionalized Endogenous Growth
}

\author{
Terutomo Ozawa
}

[individuals] know that where little wealth circulates, there is little to be got, but that where a great deal is in motion, some share of it may fall to them. The same maxim...should make a whole nation regard the riches of its neighbours as a probable cause and occasion for itself to acquire riches.

Adam Smith (1776)

\section{Introduction: Regionalized endogenous growth}

Despite the financial crises of 1997-98, East Asia as a whole has experienced unprecedented rapid growth continually since the end of World War II (WWII). During the post-WWII golden age of capitalism (1950-1971), Japan's per capita income multiplied sixfold, "growing at 8 percent a year compared with 4 percent in Western Europe. Labour productivity grew by 7.7 percent a year, compared with 4.8 percent in Western Europe, total factor productivity at 5.1 percent a year compared with 2.9 percent" (Maddison, 2001, p. 139). Japan was thus the greatest beneficiary of the postwar golden age of capitalism, with fast increases in per capita income, labor productivity, and production efficiency (up until the bursting of the 1987-90 asset bubble).

The "neoliberal order" (1971-present) then ensued. In the wake of the first oil crisis of 1973, while both Japan and Western Europe slowed down considerably with a growth rate cut more than half, "Resurgent Asia" (15 countries) actually grew faster than in the golden age. Notable were the rapid growth rates experienced by the Asian NIEs (Hong Kong, Singapore, South Korea, and Taiwan). But, shortly afterward, China began its rapid ascent once it opened 
up to the noncommunist world in 1978 (2.9 percent in per capital GDP growth rate, 1950-73, 4.8\%, 1973-90, and 6.4 per cent, 1990-99) (Maddison, 2001, p.143).

Since the end of WWII there have thus occurred two economic miracles in East Asia, the Japanese miracle and the Asian NIEs miracle. And we are presently witnessing a third one, the Chinese miracle, in the making. ${ }^{1}$ And the Chinese miracle, though still in its inchoate phase, will be no doubt the most spectacular of them all in terms of speed (time compression) of growth and structural upgrading and the most dramatic in terms of its impact on the rest of the world--but especially on neighboring countries on the Pacific Rim-because of its huge domestic market and its expected swift integration into the global economy through the WTO accession.

Be that as it may, however, why is it that such three economic miracles have occurred in tandem since WWII-- and all of them in the world's particular region, East Asia? Why not in other regions? Are they simply disparate phenomena or do they exhibit some commonalities and interconnectedness in their growth characteristics, some common causes for such a clustered regional growth? In short, why have East Asia economies grown so fast in sequential wavesand continue to grow vigorously even in the post-crisis period?

The themes of my paper are (i) that following the path of the Pax Britannica, the Pax Americana has generated powerful growth-clustering forces by way of providing a climbable ladder of industrialization and propagating growth stimuli to the world, (ii) that a model of structural upgrading (emended from the so-called "flying-geese" paradigm of economic development) is useful to explain the forces of hegemon-led macro-clustering; (iii) that Japan fully exploited such forces to its own advantage and quickly caught up to the West; (iv) that this rapid industrial upgrading of postwar Japan in turn has generated an augmentative growth force

\footnotetext{
${ }^{1}$ Actually, India may also experience an economic miracle, since it too started to open up its economy, if more slowly and gradually than China. "A quiet economic revolution" is said to have just begun.
} 
for the rest of East Asia as it served as a structural intermediator and as a capacity augmenter; and (v) that the public policies pursued by other East Asian economies have proved effective for the very reason that a favorable global environment was created by the unique roles of the U.S. (as the first lead economy from the both demand and supply sides) and Japan (as the second lead economy mainly from the supply side) in disseminating complementary stimuli through trade and investment.

\section{Hegemon-led macro-clustering}

One commonality of the three miracles is that dramatic catch-up growth has taken place under the aegis of the Pax Americana, which came into existence after WWII.

These Asian miracles are inconceivable without the role of the U.S. as the hegemon of market capitalism. The U.S. has created, and continues to maintain, a favorable global environment for trade, investment, and structural upgrading for those countries that are willing to follow its leadership by adopting a regime of market democracy.

Indeed, the Pax Americana constitutes an economic system of what may be called "hegemon-led macro-clustering" (a hegemon-driven process of tandem growth), which is actually an extended outcome of Pax-Britannica-led macro-clustering (Ozawa, 2003, in press). Macro-clustering is a phenomenon in which a hegmon economy propagates growth stimuli to its closely aligned cohort of countries (which are at lower stages of development and structural upgrading). The growth stimuli include the dissemination of technology, knowledge, skills, market information, and demand (via access to the hegemon's home markets) — and above all, growth-inducing institutional arrangements of open market capitalism; this all contributes to the higher levels of labor productivity and efficiency. The low-echelon countries can "free ride" and 
thrive on these stimuli. In other words, there is what may be called "economies of hierarchical concatenation" that the follower countries can reap from the forces of hegemon-led macroclustering. It is basically a region-wide type of economic agglomeration (or regionalized endogenous growth), in which cross-border trade and investment are fundamentally marketdriven (profit-motivated and-guided), though individual countries, especially those lowerechelon ones, are usually involved in market-enhancing dirigiste catch-up strategies. Put it simply, a hierarchy of countries led by a lead country matters - and matters a lot for regional economic growth in general and for individual countries' economic development in particular.

\section{A reformulated "flying-geese (FG)" paradigm}

As introduced elsewhere (Ozawa, 1992, 2001a, 2001b), a model of industrial upgrading can shed light on the evolutionary process of hegemon-led industrial development. This model is a reformulated version of the so-called "flying-geese (FG)" theory, which was originated in Akamatsu (1935, 1962), expanded in Kojima (1958, 2000), and Kojima and Ozawa (1994 and 1995). ${ }^{2} \quad$ The reformulated model is basically a "leading growth sector" stages model a la Schumpeter (1934), in which industrial upgrading occurs periodically accentuating a sequence of growth by stages, in each of which a certain industrial sector can be identified as the main engine of structural transformation into a higher value-added level.

As shown in Figure 1, the world economy has so far seen five tiers of industry emerge ever since the Industrial Revolution in England - five tiers conceptualized in the emended FG paradigm. The first dominant industry that appeared was what may be called "Heckscher-Ohlin" endowments-driven (natural resources and/or "raw" labor-intensive) industries (best represented 
by cotton textiles). It was soon followed by the "nondifferentiated Smithian" scale-driven (physical capitat intensive, natural resource-processing heavy and chemical industries, such as steel and basic chemicals). The golden age of capitalism, Mark I (1870-1913) stemmed from the growth of these first two phases of industrial development under the Pax Britannica. Its need—and its search-for natural resources (e.g., iron ore) and markets (for textiles and capital goods) led to colonialism overseas, and scale-driven heavy and chemical industrialization was once pursued under imperialism (as part and parcel of arms race among imperialist powers).

The rise of the Pax Americana originated from Yankee ingenuity in the innovation of interchangeable parts and assembly-line operations, which eventually culminated in the techniques of mass production—and the pattern of mass consumption (especially after WWII). The "differentiated Smithian" assembly-based industries (notably automobiles) emerged as the leading growth sector in the United States, following the introduction of Ford's assembly-lines and Frederick Taylor's scientific management. Mass production (Fordism-cum-Taylorism) emerged as the dominant manufacturing paradigm.

Then, in the post WWII period R\&D-driven industries as a new growth sector came to represent the "Schumpeterian" R\&D-driven industries (e.g., microchips, computers, telecommunications, and biotechnology). In the 1950s and 1960s, many large companies in science-based industries began to set up corporate R\&D centers. Notable were I.B.M.'s Watson Labs and AT\&T"s Bell Labs. The "age of corporate laboratories" (Best, 2001) was thus ushered into the U.S. economy, leading to America's ind ustrial leadership in many high-tech goods such as computers and electronics.

\footnotetext{
${ }^{2}$ When this FG model is interpreted as a model of "catch-up by learning," it is built on the Smithian "wealth spillover" effect which is explicit in the quote cited from Adam Smith's Wealth of Nations (1776) at the start of this paper.
} 
And most recently, emanating from the Schumpeterian industries, the Internet and other forms of information technology (IT) soon came to revolutionalize the telecommunications industry. Consequently, the Pax Americana has given birth to the "McLuhan" Internet-enabled industries (named after Marshall McLuhan, the guru of mass communication) (Ozawa, 2001b), a new phase of economic growth so far most extensively introduced in the U.S. as a consequence of the IT revolution, particularly during the latter half of the 1990s. The so-called "New Economy" was thus born. ${ }^{3}$ It is comprised of both Schumpeterian and McLuhan industries, the former providing hardware (such as super-chips, computers, and telecommunication gear), while the latter (such as software, the Internet, and contents). Indeed, the pace of globalization, which is basically the forces of Pax-Americana-led macro-clustering, has been accelerating with the IT revolution (notably, the introduction of World Wide Web).

In short, what the Pax Britannica introduced were labor-intensive industries, as typified by textiles, and "bricks and mortar" industries based mostly on natural resources ("natural capital" and "physical capital"), as epitomized by steel, basic chemicals, and heavy machinery. In contrast, the Pax Americana created highly components-intensive, assembly-based, genuinely consumer-oriented, and R\&D-intensive manufactures such as cars and electronics_-and most recently, the Net-enabled goods and services. In particular, McLuhan IT-derived industries are built on "intellectual and entrepreneurial capital" and strongly geared to the needs of final consumers. The New Economy is the latest creation of Pax Americana-led consumer capitalism.

The differentiated-Smithian, Schumpeterian, and McLuhan industries, the three tiers fostered under the Pax Americana, thus all require economic freedom as sine quo non. As

\footnotetext{
${ }^{3}$ The IT revolution is fundamentally based on personal computers (PCs). And the PC revolution itself originated in the Western half ("younger regions) of the U.S. where entrepreneurs created leading companies such as HP, Apple, Microsoft, Sun-Microsystem, and Cisco (Norton, 2001).
} 
William Baumol argues in his latest book, The Free-Market Innovation Machine: Analyzing the Growth Miracle of Capitalism (2002), the free market is the most efficient innovation machine to satisfy consumer needs and demand. Open market capitalism is therefore the necessary institution for Pax-Americana-nurtured industries. In contrast, the Old Economy industries (especially the "smoke-stack" industries) are the legacies of the Pax Brittanica and were once developed and able to thrive as the leading sectors in the advanced economies in the pre-WWII period—even under a variety of economic systems: unfettered bourgeois capitalism and colonialism (early on in Britain and other early capitalist powers), welfare socialism (in Scandinavia), communism (in the Soviet Union and China), and fascism (in Germany, Italy, and Japan).

It should be noted in passing that the collapse of the Soviet Union was in part caused by the rise of consumerism under democratic capitalism. Rostow (1960) foresightedly prognosticated the self-destructive course of Soviet communism:

In the 1950s Western Europe and Japan appear to have fully entered [the stage of high mass-consumption], accounting substantially for a momentum in their economies quite unexpected in the immediate postwar years. The Soviet Union is technically ready for this stage, and by every sign, its citizens hunger for it: but communist leaders face difficult political and social problems of adjustment if this stage is launched (p. 11).

Communism proved to be fatally incompatible with the age of consumerism. The former Soviet Union—for that matter, China before its open door policy--was stuck with the nondifferentiated Smithin industries (materiat intensive and pollution-prone) and could not successfully climb up to the Pax-Americana-led stages of high mass consumption without help from the market capitalist economies. 


\section{Demanufacturization and tertiarization in the U.S.}

As observed by Clark (1935), economic development is typically characterized by the relative decline of the primary sector, the rise of the secondary sector (manufacturing and construction), and the growth of the tertiary (services) sector-all in contiguous sequence over time. In this respect, the U.S. has experienced a rapid pace of tertiarization in recent decades, causing fears of deindustrialization or "hollowing out." In fact, "the deindustrialization wave" (Bluestone and Harrison, 1982) began to erode the soil of industrial America, starting noticeably in the 1970s. In many instances, domestic factories were closed and American firms moved their manufacturing facilities outside the country. This trend continued unabatedly into the $1980 \mathrm{~s}$-so much so that in a special report, Business Week (1986) warned a transformation of U.S. manufacturing companies into the "hollow corporation." It observed: "a new kind of company is evolving in the U.S.- - manufacturing companies that do little manufacturing. Instead, they import components or products from low-wage countries, slap their own names on them, and sell them in America."

Moreover, America's tertiarization, culminating in the emergence of the New Economy and the recent equity bubble (during the latter half of the 1990s), has been accompanied—and facilitated--by rising trade (and current-account) deficits. One important cause of this trade balance deterioration is a stepped-up transfer of manufacturing activities overseas, while American firms increasingly concentrate on knowledge creation (via R\&D), entrepreneurial risktaking, and financial services in the postindustrial economy.

This structural change was captured in the product-cycle (PC) theory of trade and investment (Vernon, 1966). It describes (i) why new high-income products and labor-saving processes are first innovated in, and exported from, the U.S. ahead of other countries, but (ii) 
why such U.S. exports are to be soon replaced by overseas production once the technology involved is perfected and standardized, making it easy for the follower firms in other countries to imitate. Furthermore, in the end the U.S. is actually to wind up importing these products, the very products it has initially innovated and exported. Thus, the PC theory can be reinterpreted as a theory of "demanufacturization" (if not precisely deindustrialization, since the most critical upstream operations, R\&D activities and product/market development, are still retained at home), because it describes an ineluctable market-driven process of industrial migration from home and propagation abroad.

In addition to this PC theory-Type 1, Vernon introduced the PC theory-Type II (1979), in which R\&D activities are, in turn, widely dispersed throughout the world via networks of multinationals' FDI--instead of being centered only in the U.S. The PC theory-Type II thus can be reinterpreted as a theory of $R \& D$ capability dispersion overseas. A full range of $R \& D$ activities (from basic research to commercialization, involving product/process engineering, designing, and development) are still controlled and managed by U.S. multinationals, but they are now carried out across borders. This dispersion facilitates immediate local production overseas-without the prolonged sequence of innovations at home $\rightarrow$ exports $\rightarrow$ technology transfers and production transplantation $\rightarrow$ imports as depicted in the PC theory-Type I.

In this connection, another version of PC theory (i.e., the PC theory-Type III) should be proposed to describe how in the early stages of R\&D activities American firms have often been induced to sell basic/seed technologies abroad through licensing agreements or other non-equity transactions-- instead of fully developing and commercializing such technologies first at home or via networks of their multinational operations. In other words, D (development) drops out of R\&D. The PC theory-Type III is, for example, quite relevant to Japan's postwar strategy to 
acquire latest Western technologies in "crude/unapplied" form under licensing and commercialize them into successful products. As rapidly catching-up economies (such as the NIEs and China) develop R\&D capabilities of their own, the Japanese experience is most likely to be replicated. In sum, all the three types of the PC model illustrate the high propensity of the United States, the hegemon economy, to propagate newly introduced products and R\&D capacities, as well as seed knowledge itself, abroad.

And America's New Economy has been—and still is—driven by what may be characterized as "financialization" (a phenomenon of tertiarization), a phase of capitalism in which the engine of growth shifts from manufacturing to financial activities such as securities investment, M\&As, IPOs, and creation/trading of derivatives. ${ }^{4}$ Many new financial products and transactions have been innovated first in the United States. And these new financial products and services have begun to similarly go through the product-cycle process of spreading to other countries.

Expectedly, the innovative U.S. financial markets have attracted huge inflows of capital from overseas (estimated to be about $\$ 2$ billion a day at one time prior to the sudden tanking of the U.S. stock market in July, 2002), leading to a large capital account surplus, which in turn caused an highly overvalued dollar and an equally large current account deficit. Consequently, the McLuhan phase of the U.S. econo my has again been transmitting growth stimuli abroad, especially to East Asia, currently the main supplier of IT hardware and services (programming and data-processing), as the U.S. absorbs large amounts of imports from East Asia—and elsewhere. 


\section{Japa n's role as the second goose}

At the end of WWII, the U.S. dominated the world in every tier of industry, ranging from the most technologically sophisticated down to the most standardized low-productivity industries, simply because the rest of the industria lized world lay in ruins. The U.S. stood on top of the world, enjoying an absolute advantage in every single manufacturing industry, as well as in agriculture, forestry, and mining (including oil). Yet it could not remain a secluded colossus.

Despite the absolute advantages in all industries, what mattered as a basis for trade was the logic of comparative advantage. And this principle was fully activated by the U.S. as an effective tool of assisting other countries, but especially East Asia in the context of the U.S. Cold War diplomacy—because of the region's strategic importance.

Japan in particular benefited enormously from this American trade policy and came to play two important roles for the rest of East Asia's subsequent catch-up industrialization, (i) as an industrial upgrading intermediary, and (ii) as a capacity augmenter.

\section{1. Industrial upgrading intermediation and production fragmentation}

Perhaps nowhere else has been observed as rapid a process of structural upgrading as has been achieved by Japan since WWII. What Japan accomplished is that it has quickly climbed up the ladder of industry, stage by stage; first from labor-intensive Heckscher-Ohlin industries (as exemplified by textiles) (from 1950 to mid-1960s) ) $^{5}$ and scale-driven non-differentiated Smithian industries (steel) (from late 1950s to early 1970s) to assembly-based differentiated Smithian industries (automobiles) (from late 1960s onward), to R\&D-driven Shumpeterian industries (computers) (from mid-1980s to the present), and finally to IT-based McLuhan industries (the Internet) (mid-1990s onward)--all along the path of industrial upgrading trodden by the West

\footnotetext{
${ }^{4}$ As Mandel (2000) succinctly put it, "If technology is the engine for the New Economy, then finance is the fuel."
} 
under the Pax-Britannica and the Pax-Americana. ${ }^{6}$ This swift industrial upgrading involved a move toward a higher value-added level of activity. And Japan was able to accomplish this feat by means of dynamic infant-industry protection and the absorption of advanced industrial knowledge from the West largely through licensing agreements in the post-WWII period. Structural upgrading has been a major source of Japan's productivity growth.

Although Japan eagerly borrowed foreign technologies, its absorptive effort was not mere imitation. In the process of adopting and adapting state-of-the-art technologies, Japanese industry has introduced numerous improvements, notably in techniques of commercialization. New ways of arranging production (process and plant-layout technologies) have been innovated even in such a traditional industry as steel. For example, a speedier adoption of oxygen converter in Japan than anywhere else (Lynn, 1982) and the introduction of continuous casting and forging, along with the development of new light gauge steel, seamless electrical pipe, high tensile strength steel, etc. (Kosai, 1986). A variety of consumer electronics products (such as miniaturized transistor radios and TV sets, calculators, digital watches, video-recorders, and CD players) have been innovated one after another out of basic technologies (e.g., transistors).

During its catch-up phase of building up an efficient automobile industry in a relatively small domestic market, Japan technologically overhauled American-style assembly-based production by innovating so-called "flexible or lean production" (also known as the Toyota production system) (Ohno, 1978; Womack, Jones, and Roos, 1990). “Just-in-time” parts delivery replaced "just-in-case" inventory. This flexible production relies heavily on a cooperative group of suppliers of parts, components, and accessories (PCAs) down the stream of

\footnotetext{
5 Japan actually reached the "nondifferentiated Smithian" stage of growth already in prewar days but modernized war-torn heavy and chemical industries in the postwar period

${ }^{6}$ Japan had already gone through the first two stages in the pre-WWII period. In fact, Akamatsu originally found FG patterns (import->local production->export) in the development of Japan's labor-intensive manufacturing (such
} 
a sequential production process. PCAs are extensively outsourced instead of being produced inhouse. In other words, the vertical integrated stages of production are "fragmented" between final assemblers and their suppliers, as well as among different layers of suppliers themselves. ${ }^{7}$

Furthermore, because of the "dual" (or actually multi-layered) industrial structure of Japanese industry (where large, medium, and small firms coexist in close affiliations), process fragmentation (vertical specialization) has become all the more fine-tuned to make use of different labor costs and technological capabilities of suppliers at divergent levels of Japan's industrial hierarchy. Fragmentation is thus even more pronounced in Japan's assembly-based industries than anywhere else because of the introduction of lean production.

Yet, Japan could not retain the whole segments of the fragmented production process at home. Rapid increases in labor costs in Japan, combined with the outward move of major assemblers overseas, have been compelling suppliers, especially those which produce relatively labor-intensive PCAs, to shift production to low-wage locations in neighboring countries. Thus, fragmentation itself facilitates such segmented-process transplantation.

Process fragmentation has not been limited to the Smithian assembly-based industries alone, albeit they have been most amenable to it because of the intensive use of PCAs. As Japan moved up the ladder of structural upgrading, each tier of industry became vertically differentiated in technological sophistication, value-added, product quality, and factor intensity. For example, in scale-driven heavy and chemical industries a hierarchy of products developed in terms of differentiation along the lines of, say, crude steel vs. stainless or high-tension steel, and basic chemicals vs. refined chemicals. In the assembly-based automobile industry, cars are

as woolen goods and cotton yarn and cloth) and light-machinery industry (spinning and weaving machines and machine tools) before WWII. Heavy and chemical industries were also set up in order to support Japan's militarism. 
differentiated by high-end vs. low-end models - and its parts, components, and accessories by high value-added key components vs. low value-added peripherals. R\&D activities are differentiated in terms of basic vs. applied/adaptive research. Even the latest leading sector, the IT industry, covers a wide range of activities running from relatively low value-added (e.g., dataprocessing) to highly sophisticated software development.

Each higher tier of industry, thus, offers to developing countries opportunities to participate in some low-end segments of production and service which are commensurate with their levels of technological sophistication and wages. In other words, developing countries with advantages in labor-intensive standardized goods can now join not only in lowest-tier (Heckscher-Ohlin) light industries but also in the low-end of each of higher-tier industries. Thus, an intra-industry vertical division of labor occurs across borders, along with an interindustry horizontal division of labor.

As a consequence, Japan's step-by-step industrial upgrading has had an enormous impact on the industrialization pattern of other East Asian countries. As Japan lost comparative advantages in low-productivity tiers (or low-end goods at each tier), it transplanted via FDI those disadvantaged industrial activities to other Asian economies (first to the NIEs, then to ASEAN-4, and most recently to China) where they could still produce competitively. In fact, this form of industrial shedding and comparative advantage recycling (Ozawa, 1993) have been serving as an industrial structural facilitator for the region as a whole.

It is worth noting that when a country loses a comparative/competitive advantage in a particular productive activity, two types of assets/resources are released from the contracting

\footnotetext{
${ }^{7}$ The notion of production fragmentation has recently been formally theorized. A survey of the literature is provided in Jones (2000). A systematic effort to theorize this phenomenon is also made by noted theorists in Arndt and Kierzkowski (2001).
} 
sector: (i) those readily transferable to the expanding sector (namely, homogeneous, nonsectorspecific resources, such as land and labor); and (ii) those specific to the contracting sector and, therefore, nontransferable to the expanding sector (for example, industry/firm- specific technology, knowledge, and experiences). Most resources of the first type of resources, however, are nontransferable to other countries because of institutional or physical constraints. On the other hand, the second type of resources released will be actually wasted at home unless they are transferred to and employed in other countries where such industry/firm-specific resources are needed to develop comparatively advantaged production. Through this mechanism, the resources released from the contracting sector at home are reused (instead of being discarded) and transformed into dividends from FDI operations. The end result is a rise in output and income for both home and host countries, thereby contributing to regionally clustered growth.

\subsection{Capacity augmenter}

In climbing up the ladder of industrial upgrading, notably the differentiated Smithian rung of components-intensive, assembly-based industries, all the Asian follower countries' export-led growth has become dependent on imported PCAs from the advanced countries, especially from Japan. Park and Park (1991:93) makes a pertinent observation:

[The NIEs] have relied on Japan as their main supplier of capital and intermediate goods... Almost 80 percent of [their] imports from Japan in the 1980s included capital and technology-intensive manufactures. This dependence on Japan for capital and technology has increased in recent years. In 1987, [the NIEs] obtained from Japan almost 50 percent of their total imports of technology-intensive manufactures (up from about 41 percent in 1980) as compared to 26 percent form the United States.

Similarly, Thurow (1996:207) argues:

On the Pacific Rim, countries run big trade deficits with Japan, which they finance out of their trade surplus with the United States... China's 1995 trade surplus with 
Japan is ...misleading since it sells Japanese components that are installed on products that are exported to Europe and America.

In fact, Sinohara (1987) much earlier argued that Japan interacts with the rest of East Asia more strongly from the supply side (i.e., as a capacity augmenter) than from the demand side (i.e., as a market provider). In an econometric study, Nakamura and Matsuzaki (1997) similarly demonstrated Japan's role of capacity augmenter by way of an international input-output analysis and concluded that Japan developed more of a supply-sided relationship with the rest of East Asia.

Thus, given this role of Japan, it is expected that the more successful other Asian countries are in developing export-driven manufacturing, the greater their dependence on input supplies from Japan—hence the more unfavorable their trade balance vis-à-vis Japan. But these developing countries also have recently started to rely on local production of PCAs by multinationals, especially from Japan.

The same role of a capacity augmenter is now being played increasingly by the NIEs (notably South Korea and Taiwan which are more manufacturing-focused than Hong Kong and Singapore) in supplying PCAs to ASEAN-4 and China. This development is deepening an intra-Asian division of labor in manufacturing and trade.

Looked at in the above light, East Asian economies are not simply export-driven but at the same time strongly import-driven; imports of industrial knowledge, capital goods, and supplies, especially through foreign multinationals' operations, are critical for the success of export-driven local industries. Hence, an "import- and export-led growth" paradigm (Klein, 1990; Dutta, 1999, 2000) is most appropriate for East Asia's growth-excepting Japan which built up a rather self-sufficient industrial structure under infant-industry protection and without much reliance on imported capital goods. The paradigm of import- and export-led growth is 
both trade- and FDI-augmenting, since foreign investments in labor-abundant economies "were to be paid for by sharing revenues from export earnings which generated a pool of hard currency. The profit repatriation home by foreign investors thus became a way of operation, which in turn induced additional inflow of foreign investment" (Dutta, 2000, p. 71).

\section{Export competitiveness and currency appreciation}

It is well known that developing countries' currencies tend to remain undervalued rela tive to advanced countries' currencies (Kravis and Lipsey, 1983; Bhagwati, 1984). In fact, their governments like to keep their currencies undervalued to gain export competitiveness and protect domestic industries. An undervalued home currency is usually a plus factor in export-led growth. Yet, the very success of such a development strategy inevitably and eventually leads to home currency appreciation in the foreign exchange market as its trade balance improves. (If the exchange rate is nominally fixed, the currency becomes even more undervalued—i.e., real exchange rate depreciation. This may strain trade relationships with other countries and cause excessively high domestic prices of imported capital goods and industrial materials. In other words, the benefits of undervalued currency begin to be outweighed by the costs.)

In the wake of Japan's rapid catch-up with its current account surplus rising, the Japanese yen became grossly undervalued and soared in market value once the fixed exchange rate was abandoned in 1973. The yen gained more than fourfold in value at one time in 1995 over the previously fixed rate which once prevailed under the original IMF system (i.e., from Y360/\$ in 1970 to Y80/\$ in April, 1995). Actually, the yen became grossly overvalued, compelling Japanese firms to transplant production to neighboring countries, especially ASEAN-4 and China, whose currencies were more or less tied to the U.S. dollar and hence undervalued. In 
fact, the overvalued yen led to surging waves of outward FDI over the 1986-1996 period. Many Japanese firms moved out of Japan not so much because they lost real competitive/comparative advantages, but rather because the abnormally high yen made it disproportionately more costly to produce at home than abroad (Ozawa, 2001a).

Although less pronounced, a similar exchange-rate effect has been observable in the NIEs' overseas investments in ASEAN-4 and China. In 1985, the NIEs' currencies also began to exhibit a secular trend of appreciation, though more moderately than the yen. In contrast, ASEAN-4's and China's currency in particular exhibited a dramatic depreciation (undervaluation), since they are still in the relatively early stages of catch-up. These contrasting trends in exchange rates no doubt played a key role in the rapid transmigration of labor-intensive industries, first from Japan to neighboring countries and then from the NIEs to ASEAN-4 and China. In short, the staggered trends of changes in currency values among the East Asian economies at different stages of economic growth is another factor for comparative advantage recycling through FDI in East Asia-in addition to increasing wage differentials that develop during the course of rapid growth.

\section{Public policies on the part of catching-up economies}

We have so far examined the roles of the first lead goose (the U.S.) and the second goose (Japan) in transmitting growth stimuli by way of transferring technology, knowledge, and information through international business activities, notably FDI. But what has made the East Asian Miracle possible is that the follower geese themselves have been capable of capturing and exploiting such favorable external conditions. In other words, for a regionally clustered growth 
to occur, the emulator countries must possess what Abramovitz (1986) calls "social capability" for learning and catch-up. But what is exactly the social capability?

According to the World Bank (1993), the high-performing Asian Economies (HPAEs) ${ }^{8}$ got the fundamentals right by way of (i) carefully limited and "market-friendly" government activism, (ii) strong export orientation, (iii) high levels of domestic savings, (iv) accumulation of human and physical capital, (v) good macroeconomic management, (vi) acquisition of technology through openness to direct foreign investment and licensing, (vii) flexible labor markets, and (viii) shared growth (spreading the benefits of growth to all groups. It should be noted that all these features are directly or indirectly related to pro-business activism. Indeed, the government mattered, and mattered a lot_-in building market-compatible (if not totally market-dictated) economies. This is in sharp contrast to the neoclassical stance to place full trust in the market mechanism.

In this regard, it should be noted that the World Bank, a proselytizer of market capitalism, initially resisted to a proposal to study East Asian growth and that only after Japan agreed to pay for it, a team of researchers finally proceeded. As explained by Stiglitz (2001) who led that research,

The reason was obvious: The countries had been successful not only in spite of the fact that they had not followed most of the dictates of the Washington Consensus, but because they had not. Though the experts' findings were toned down in the final published report, the World Bank's Asian Miracle study laid out the important roles that the government had played. These were far from the minimalist roles beloved of the Washington Consensus (p. 91).

There is an abundance of literature on the role of the government in East Asian growth (inter alia, Amsden, 1989, 2001; Wade, 1990: Aoki, Kim, and Okuno-Fujiwara, 1997), hence no need

\footnotetext{
${ }^{8}$ The HPAEs in the World Bank study consist of Japan, Hong Kong, Korea, Singapore, Taiwan, Indonesia, Malaysia, and Thailand.
} 
here to detail it. It suffices to say that East Asian economies' social capabilities are neither innate nor manna from Heaven but has been created and governed by the governments.

The World Bank study focused mostly on the individual economies' internal policies and institutions, and did not delve into the question of how growth externalities (stimuli and incentives) were generated and propagated to the HPEAs. The effectiveness of growthpromoting policies and practices at the individual country's level was dependent on how each economy responded to and exploited the external environment and opportunities by means of public policies. This point appears to be supported by a recent statistical study; Using data for 11 economies in East Asia and Latin America, Zhang (2002, p. 175) found that "although FDI is expected to boost host economic growth, it is shown that the extent to which FDI is growthenhancing appears to depend on country-specific characteristics "(such as liberalized trade regime, improved education and human capital conditions, export-oriented FDI, and macroeconomic stability).

\section{Conclusions}

East Asia has seen rapid growth in tandem--first in Japan, then in the NIEs, later in ASEAN-4 and most recently in China. They have been the beneficiaries of Pax-Americana-led macro-clustering. Japan's successful catch-up and joining the ranks of the advanced economies had mostly been completed by the end of the post-WWII golden age of capitalism (1950-1971) during which exchange-rate stability was maintained and capital controls were tolerated to shield the national financial markets. The Japanese government was heavily involved in "infant industry" protection strategies by restricting trade and inward FDI so as to build up national (not foreign-owned) domestic industries. 
Among the NIEs, South Korea and Taiwan initially followed many features of the Japanese model of catch-up but soon became increasingly more open to, hence more dependent on, inward FDI, thereby departing from the Japanese model. Hong Kong and Singapore, which are less manufacturing-focused and more service-based, both have long been totally open to inward FDI. ASEAN-4's export competitiveness in manufactures (notably electronics) derives from foreign multinationals' operations. Ever since the adoption of its open-door policy in 1978, China has been benefiting from stepped-up integration with the outside world through active trade and inward FDI.

In sum, East Asia has been blessed, first of all, by the presence of the U.S., the hegemon of the post-WWII global economic system, which is the major provider of industrial knowledge and markets_-and secondly, by the roles of Japan as a structural intermediator and as a capacity augmenter, the roles which the NIEs themselves in turn have recently begun to play. The existence of these strong secondary geese is what makes a regionalized endogenous growth possible in, and endemic to, East Asia. No doubt, East Asian growth has been the most successful outcome of Pax-Americana-led macro-clustering. 


\section{References}

Abramovitz, Moses (1986). "Catching up, forging ahead, and falling behind," Journal of Economic History XLVI (2): 385-406.

Akamatsu, Kaname (1935). Wagakuni yomo kogyohin no susei [Trend of Japan's wooden product industry], Shogyo Keizai Ronso, 13, 129-212.

Akamatsu, Kaname (1962). A historical pattern of economic growth in developing countries. Developing Economies, 1, 1-23.

Amsden, Alice H. (1989). Asia's Next Giant: South Korea and Late Industrialization, New York: Oxford University Press.

Amsden, Alice H. (2002). The Rise of "the Rest": Challenges to the West from lateIndustrializing Economies, New York: Oxford University Press.

Aoki, Masahiko, Kim, Hyung-Ki, and Okuno-Fujiwara, Masahiro (eds.) (1995). The Role of Government in East Asian Economic Development: Comparative Institutional Analysis, Oxford: Clarendon Press.

Armdt. Sven W. and Kierzkowski, Henryk (eds.). (2001), Fragmentation: New Production Patterns in the World Economy, Oxford: Oxford University Press, 2001.

Baumol, William (2002), The Free-Market Innovation Machine. Analyzing the Growth Miracle of Capitalism, Princeton: Princeton University Press.

Best, Michael H. (2001). The New Competitive Advantage: The Renewal of American Industry, Oxford: Oxford University Press.

Bhagwati, Jagnish (1984). "Why Are Services Cheaper in the Poor Countries?" Economic Journal 94 (June): 279-280.

Bluestone, Barry and Harison, Bennett (1982). The Deindustrialization of America: Plant Closings, Community Abandonment, and the Dismantling of Basic Industry, New York: Basic Books.

Clark, Colin (1935). The Conditions of Economic Progress, London: Macmillan.

Dutta, Manorijan (1999). Economic Regionalization in the Asia-Pacific, Cheltenham, Glos: Edward Elgar.

Dutta, Manorijan (2000). "The euro revolution and the European Union: monetary and economic cooperation in the Asia-Pacific region," Journal of Asian Economics 11: 65-88. 
Jones, Ronald W. (2000). Globalization and the Theory of Input Trade, Cambridge, MA: MIT Press.

Klein, Lawrence R. (1990). "Can export-led growth continue indefinitely? An Asian-Pacific perspective,“ Journal of Asian Economics 1 (1), 1-12.

Kojima, Kiyoshi (1958). Nihon Keizai no gankokeitaiteki hatten to boeki no yakuwari [Flyinggeese-style growth of the Japanese ecoomy and the role of trade]," reproduced in Kiyoshi Kojima (ed.), Nihon Boeki no Kozo to Hatten [The Structure and Growth of Japan's Trade], Tokyo: Shiseido.

Kojima, Kiyoshi (2000). "The 'flying-geese' model of Asian economic development: origin, theoretical extensions, and regional policy implications," Journal of Asian Economics, 11, 375401.

Kojima, Kiyoshi and Ozawa, Terutomo (1984). "Micro- and macro-economic models of direct investment: toward a synthesis, Hitotsubashi Journal of Economics, 25 (1), 1-20.

Kojima, Kiyoshi and Ozawa, Terutomo (1985). "Toward a theory of industrial restructuring and dynamic comparative advantage," Hitotsubashi Journal of Economics, 26 (2), 135-145.

Kosai, Yutaka (1986). The Era of High Speed Growth: Notes on the Postwar Japanese Economy (English translation), Tokyo: University of Tokyo Press.

Kravis, Irvin B.and Robert. E. Lipsey (1983). Toward an Exploration of National Price Levels, Princeton Studies in International Finance 52 (International Finance Section, Department of Economics, Princeton University), November.

Lynn, Leonard H. (1982). How Japan Innovates: A Comparison with the U.S. in the Area of Oxygen Steelmaking, Boulder, Colo.: Westview Press.

Maddison, Angus (2001). The World Economy. A Millennial Perspective. Development Centre Studies, Paris: OECD.

Mandel Michael (2000). The Coming Internet Depression, New York: Basic Books.

Nakamura, Yoichi and Matsuzaki, Izumi (1997). "Economic interdependence: Japan, Asia, and the world," Journal of Asian Economics, 8 (2), 199-224.

Norton, R. D. (2001). Creating the New Economy: The Entrepreneur and the U.S. Resurgence, Cheltenham, UK, and Northampton, MA., Edward Elgar.

Ohno, Tai'ichi (1978). Toyota Seisan Hoshiki: Datsu-kibo no Keiei o Mezashite [Toyota Production Formula: Toward Non-scale-based Management], Tokyo: Daiyamondo. 
Ozawa, Terutomo (1992). "Foreign Direct Investment and Economic Development," Transnational Corporations, 1 (1), 27-54.

Ozawa, Terutomo (2001a). “The `hidden’ side of the `flying-geese’ catch-up model: Japan’s dirigiste institutional setup and a deepening financial morass," Journal of Asian Economics, 12, 471-491.

Ozawa, Terutomo (2001b). "The Internet revolution, networking, and the 'flying-geese' paradigm of structural upgrading, “ Global Economy Quarterly, 11, 1-18.

Ozawa, Terutomo (2003). "Toward a theory of hegemon-led macro-clustering," in Peter Gray (ed.), Extending the Eclectic Paradigm in International Business, Cheltenham, Glos: Edward Elgar, pp.201-225 (forthcoming).

Park, Yung Chul and Park, Won-Am (1991). "Changing Japanese Trade Patterns and the East Asian NICs," in Paul Krugman (ed.), Trade with Japan: Has the Door Opened Wider? NBER project, Chicago: University of Chicago Press, pp. 85-115.

Rostow, W. W. (1960). The Stages of Economic Growth: A Non-Communist Manifesto, Cambridge: Cambridge University Press.

Schumpeter, Joseph A. (1934). The Theory of Economic Development, New York: Oxford University Press (Trans.: original work published in 1911).

Sinohara, Miyohei (1987). "Patterns and backgrounds of dynamics in the Asia-Pacific economies," in Dutta, M. (ed.), Asia-Pacific Economies: Promises and Challenges, Greenwich, CT: JAI Press, Part A, 23-48.

Smith, Adam (1776). An Inquiry into the Nature and Causes of the Wealth of Nations, London: Routledge, reproduced, New York: E.P. Dutton, 1908.

Stiglitz, Joseph E. (2002). Globalization and Its Discontents, New York: W.W. Norton.

Thurow, Lester C. (1996). The Future of Capitalism: How Today's Economic Forces Shape Tomorrow's World, New York: William Morrow.

Vernon, Raymond (1966). "International investment and international trade in the product cycle," Quarterly Journal of Economics, 80 (2), 190-207.

Vernon, Raymond (1979). "The product cycle hypothesis in the new international environment," Oxford Bulletin of Economics and Statistics, 41 (4).

Wade, Robert (1990). Governing the Market: Economic Theory and the Role of Government in East Asian Industrialization, Princeton: Princeton University Press.

Womack, James P., Daniel T. Jones, and Daniel Roos (1990). The Machine that 
Changed the World, New York: Macmillan.

World Bank (1993). The East Asian Miracle: Economic Growth and Public Policy, New York: Oxford University Press.

Zhang, Kevin H. (2001). "Does foreign direct investment promote economic growth? Evidence from East Asia and Latin America," Contemporary Economic Policy, 19 (2), 175-185. 
Figure 1 Structural upgrading under Pax Britannica-led and Pax Americana-led macro-clustering

Pax Britannica

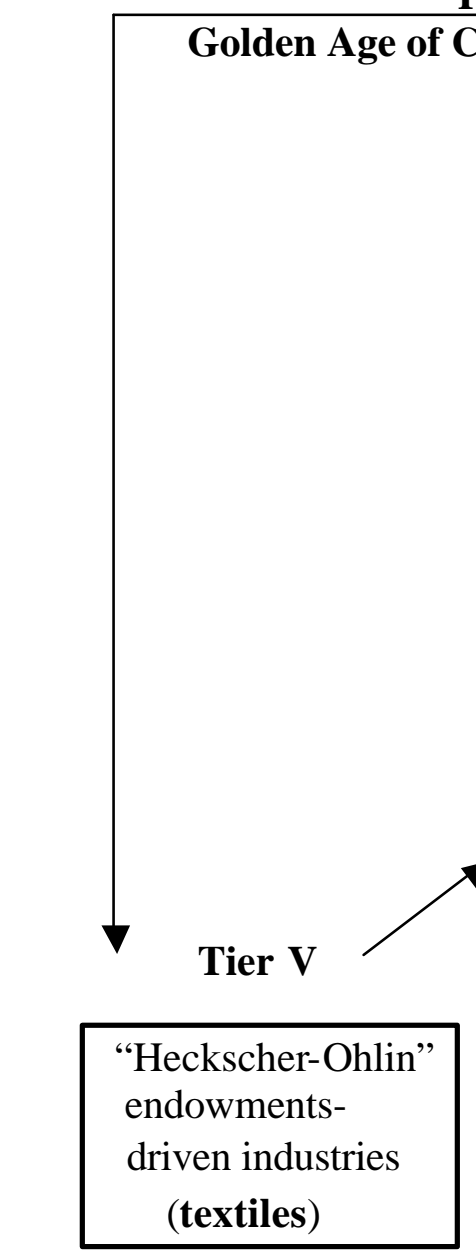

Papitalism, Mark

Tier IV
Pax Americana Golden Age of Capitalism, Mark II (1950-1971)-->Present WWII Tier I

"McLuhan" Internet-based industries (information)

Tier II

"Nondifferentiated Smithian" scaledriven industries (steel \& chemicals)

"Schumpeterian" R\&D-driven industries (microchips \& computers)

\section{Bourgeois Capitalism/Colonialism/ Communism/Fascism}

"Differentiated Smithian" assemblyBased industries (automobiles)

Natural resources-based manufacturing /elitist consumption Production primary

$\rightarrow$ Knowledge-based manufacturing

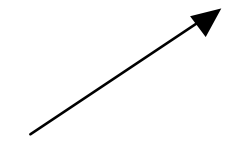

\section{Market Capitalism}

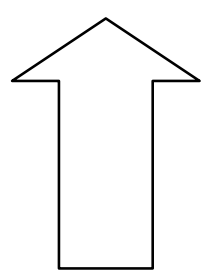

\section{Endowed assets (home-bounded)}

$\rightarrow$ High mass consumption

Natural capital

Physical capital Created assets (Foot-loose)

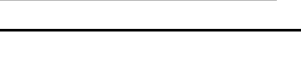

Physical capital 